Jurnal Keperawatan Silampari

Volume 2, Nomor 1, Desember 2018

e-ISSN: 2581-1975

p-ISSN: 2597-7482

DOI: https://doi.org/10.31539/jks.v2i1.341

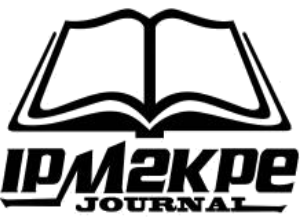

\title{
PENGARUH PENGGUNAAN SMARTPHONE TERHADAP PERKEMBANGAN PERSONAL SOSIAL ANAK USIA PRA-SEKOLAH
}

\author{
Heni $^{1}$, Ahmad Jalaludin Mujahid ${ }^{2}$ \\ Program Studi Ilmu Keperawatan, STIKES YPIB Majalengka ${ }^{1,2}$ \\ heniediani@gmail.com ${ }^{1}$
}

\begin{abstract}
ABSTRAK
Tujuan penelitian ini untuk mengetahui pengaruh penggunaan smartphone terhadap perkembangan personal sosial anak usia pra sekolah di TK Al-Marhamah. Penelitian ini menggunakan metode penelitian kuantitatif dengan desain cross sectional. Hasil penelitian menunjukan lebih dari setengahnya anak usia pra sekolah adalah pengguna smartphone dengan frekuensi sering dengan jumlah sebanyak 24 anak (72.7\%). Kurang dari setengahnya anak usia pra sekolah mengalami perkembangan yang meragukan dengan jumlah sebanyak 15 anak (45.5\%). Hasil uji statistik diperoleh nilai p 0,017. Simpulan, ada hubungan yang signifikan antara penggunaan smartphone dengan perkembangan personal sosial anak pra sekolah di Al-Marhamah Kabupaten Majaelngka Tahun 2017.
\end{abstract}

Kata Kunci: Anak Usia Pra-Sekolah, Perkembangan Personal, Smartphone

\begin{abstract}
The purpose of this study was to determine the effect of the use of smartphones on the personal social development of pre-school age children in Al-Marhamah Kindergarten. This research uses quantitative research methods with cross sectional design. The results showed more than half of pre-school age children are smartphone users with frequent frequency with 24 children (72.7\%). Less than half of pre-school-aged children experience doubtful development with a total of 15 children (45.5\%). Statistical test results obtained $p$ value of 0.017. Conclusion, there is a significant relationship between smartphone usage and the personal social development of preschool children in Al-Marhamah, Majaelngka Regency, 2017.
\end{abstract}

Keywords: Pre-School Age Children, Personal Development, Smartphones 


\section{PENDAHULUAN}

Perkembangan teknologi semakin berkembang dengan pesat sesuai dengan perkembangan zaman. Teknologi muncul berbagai macam jenis dan fitur dari teknologi selalu baru dari hari ke hari. Kebutuhan teknologi merupakan salah satu kebutuhan penting saat ini. Hal ini disebabkan karena teknologi sangat dibutuhkan untuk keperluan banyak. Teknologi sangat mudah didapatkan karena harga ada yang murah dan ada juga yang mahal sesuai dengan kantong ekonomi penggunanya (Sari, Mitsalia, 2016).

Schwartz menyebutkan anak mengalami perkembangan yang luar biasa pada tahun pertama kehidupan mereka, selain perkembangan fisik kognitif, diawal kehidupan anak terdapat pula perkembagan sosial dan emosional. Penelitilain seperti De Laune \& Ladner (dalam Nuzlia, 2015) mengemukakan lima tahun kehidupan anak sangat berpengaruh pada perekembangan sosial dan emosional mereka. Selama tahap usia prasekolah, perkembagan fisik melambat sedangkan tahapan sosial emosional dan kognitif semakin cepat.

Secara garis besar perkembangan sosial emosional mencakup perkembangan emosi dan perkembangan sosial. Goleman (2016) mengemukakan bahwa "emosi pada dasarnya adalah dorongan untuk bertindak yang didasarkan pada perasaaan, keadaan biologis dan psikologis". Kemudian Hurlock (dalam Nugraha dan Rachmawati, 2008) mengemukakan bahwa "perkembangan sosial merupakan perolehan kemampuan berperilaku yang sesuai dengan tuntutan sosial".

Anak usia pra sekolah perlu untuk mengatur emosi dalam dirinya dalam rangka mempertahankan interaksi sosial yang baik. Selaras dengan pernyataan Schwartz (dalam Nuzlia, 2015) tentang survey di Kanada menunjukan bahwa anak pra sekolah yang tinggal di lingkungan dengan ikatan sosial yang buruk memiliki masalah kemampuan bahasa dan masalah perilaku yang lebih tinggi dibanding anak pra sekolah yang tinggal dilingkungan sejahtera. Kegiatan sosial akhir-akhir ini sangat berkembang, perkembangan ini tak luput dari kemajuan teknologi dan perkembangan zaman. Kemajuan teknologi tersebut tanpa disadari membawa dampak besar yang mampu mempengaruhi perkembangan interaksi sosial.

Menurut John W. Santrock (2007) masa pra sekolah (early childhood) merupakan periode perkembangan yang terjadi mulai akhir bayi sekitar usia 5 atau 6 tahun; kadang periode ini disebut tahun-tahun pra sekolah. Selama waktu tersesbut, anak kecil belajar menjadi mandiri dan merawat diri sendiri, mereka mengembangkan keterampilan kesiapan sekolah (mengikuti perintah mengenali huruf), dan mereka menghabiskan berjam-jam untuk bermain dengan teman sebaya kelas satu Sekolah Dasar biasanya menandai akhirnya periode ini.

Adapun karakter anak pra sekolah menurut Trianto (2010) ada empat karakter. Karakter tersebut adalah cirri khas secara jasmani yaitu sangat aktif senang berlari dan melompat, pertumbuhan amat cepat dan banyak bergerak, cenderung melakukan hal-hal yang terlalu sulit, pita suara secara bertahap mulai berkembang. Ciri khas secara mental yaitu daya konsentrasi sangat pendek, rasa ingin tahu sangat besar, imajinasinya kuat, konsep terhadap "waktu" dan "ruang"masih terbatas, suka mendengarkan cerita, suka bertanya karena rasa ingin tahu yang besar, belum dapat membedakan antara ceritayang sebenarnya dengan dongeng atau khayalan. Ciri khas secara emosi yaitu sifat ketergantungan masih besar, namun juga ingin menonjolkan sifat kemandirian, suka mengatakan "tidak" dan dalam proses masa atau tahap "menentang", egosentris, egoistism, ada suatu perasaan takut, emosi masih berimbang, mudah marah tetapi juga cepat reda. Ciri khas secara sosial atau pergaulan (4-6 tahun) yaitu senang bermain 
dengan teman sebayanya, namun juga perlu waktu untuk bermain sendiri, sifat individu masih sangat kuat, sering timbul pertengkaran saat bermain, sangat membutuhkan perhatian dari orang dewasa dan sedang belajar membuat pilihan-pilihan yang benar.

Beberapa tahun yang lalu gadget hanya banyak dipakai oleh para pembisnis dari kalangan menengah ke atas. Alasan mereka menggunakan gadget adalah untuk memudahkan bisnis mereka. Namun pada zaman sekarang, gadget tidak hanya dipakai oleh para pembisnis saja, banyak para remaja bahkan anak-anak pun telah banyak menggunakan gadget. Suhandi (dalam Efendi, 2013) mengemukakan "Semakin banyak produk yang ada dipasaran, maka semakin tinggi pula tingkat konsumtif pelaku pasar".

Kementrian Komunikasi dan Informatika Republik Indonesia (2015) menjelaskan dalam situs resminya bahwa Indonesia adalah "raksasa teknologi digital Asia yang sedang tertidur". Jumlah penduduk Indonesia yang mencapai 250 juta jiwa adalah pasar yang besar. Pengguna smartphone Indonesia juga bertumbuh dengan pesat. Lembaga riset digital marketing emarketer memperkirakan pada 2018 jumlah pengguna aktif smartphone di Indonesia lebih dari100 juta orang. Dengan jumlah sebesar itu, Indonesia akan menjadi Negara dengan pengguna aktif smartphone terbesar keempat di dunia setelah Cina, India, dan Amerika.

Indonesia sendiri termasuk dalam peringkat "lima besar" negara pengguna gadget, khususnya smartphone. Data yang diambil tahun 2014 itu menunjukkan bahwa pengguna aktif smartphone adalah sekitar 47 juta, atau sekitar 14 persen dari seluruh pengguna handphone (Wulandari, 2016). Telepon pintar (smartphone) adalah telepon genggam yang mempunyai kemampuan tinggi, kadang-kadang dengan fungsi yang menyerupai komputer. Belum ada standar pabrik yang menentukan arti telepon pintar. (Elcom, 2011).

Adapun smartphone menurut para ahli lainya adalah telepon selular dengan mikroprosesor, memori, layar dan modem bawaan. Smartphone merupakan ponsel multi media yang menggabungkan fungsionalitas $P C$ dan handset sehingga menghasilkan gadget yang mewah, di mana terdapat pesan teks, kamera, pemutar musik, video, game, akses email, tv digital, search engine, pengelola informasi pribadi, fitur GPS, jasa telepon internet dan bahkan terdapat telepon yang juga berfungsi sebagai kartu kredit (Williams, Sawyer, 2007).

Bila dilihat dari Survei yang dilakukan oleh Kementerian Informasi danUNICEF tahun 2014 yang mengelompokan komposisi usia, persentase pengguna gadget yang termasuk kategori usia anak-anak dan remaja di Indonesia cukup tinggi, yaitu 79,5\%. Survei tersebut menggambarkan pula bahwa anak menggunakan gadget sebagian besar untuk mencari informasi, hiburan, serta menjalin relasisosial. Adapun survei yang dilakukan oleh Indonesia Hottest Insight ditahun 2013 bahkan menunjukkan bahwa 40 persen anak di Indonesia sudah melek teknologi, atau disebut juga dengan active internet user (Wulandari, 2016).

Menurut data di wilayah kerja UPTD Puskesmas Majalengka jumlah anak TK diseluruh Kecamatan Majalengka Kabupaten Majalengka tahun 2016 memcapai 865 anak yang tersebardi 28 TK diwilayah Kecamatan Majalengka. Berdasarkan hasil studi pendahuluan yang dilakukan peneliti di TK Al-Marhamah Kabupaten Majalengka pada tanggal 20 Februari 2016 bahwa dari 7 anak diantaranya mengemukakan bahwa bermain smartphone itu sangat menyenangkan dan 2 orangtua murid menyatakan bahwa anaknya suka minta gadgetnya untuk bermain game, namun ada juga orang tua murid menyatakan anak suka diberikan aplikasi pembelajaran dalam smartphonenya seperti penghitungan, belajar menggambar dan baca tulis. Sekolah ini dipilih karena merupakan 
TK dengan program regular yang melakukan kegiatan di sekolah sekitar dua sampai tiga jam sehingga anak memiliki banyak waktu untuk bermain smartphone dirumahnya, berbeda dengan TK fullday seperti TK GISPY Kabupaten Majalengka yang memiliki kegiatan tambahan di sekolahnya sehingga meminimalisir anak untuk bermain dengan smartphonenya walaupun murid di TK tersebut kebanyakan orang beradaptasi mereka dengan jadwalnya kemungkinan untuk bermain smartphone hanya sedikit. Berbeda dengan TK Al-Marhamah yang ber-basic regular dan didukung letak geografisnya TK ini yang berada di pusat kota Majalengka memungkinkan tinnginya dampak smartphone yang dipengaruhi oleh teman dan lingkungan. Namun tidak bisa dipungkiri bahwa exisnya teknologi ini sudah mulai marak kepenjuru desa, bahkan didesa-desa yang letaknya jauh dari kota. Adapun tujuan pada penelitian ini adalah untuk mengetahui pengaruh penggunaan smartphone terhadap perkembangan personal social anak usia pra sekolah di TKAl-Marhamah.

\section{METODE PENELITAN}

Penelitian ini menggunakan metode penelitian kuantitatif dengan desain cross sectional. Populasi dalam penelitian ini adalah seluruh orang tua murid dan siswa-siswi TK Al-Marhamah Kabupaten Majalengka dengan jumlah sampel sebanyak 33 ibu/pengaruh dan 33 anak, teknik pengambilan sampel menggunakan simple random sampling. Pelaksanaan ini dilakukan di TK Al-Marhamah Kecamatan Majalengka Kabupaten Majalengka pada tanggal 12 Mei 2017. Alat pengumpulan data yang digunakan dalam penelitian ini adalah kuesioner untuk penggunaan smartphone terhadap perkembangan personal sosial anak usia pra sekolah. Cara pengumpulan data dilakukan dengan memberikan inform consent terlebih dahulu terhadap orangtua murid/pengasuh yang dibantu oleh guru TK Al-Marhamah dan memberikan lembar persetujuan terkait penelitian yang akan dilakukan berikut penjelasannya tentang penelitian beserta cara pengisian kuesioner yang akan berlangsung di TK tersebut. Kemudian peneliti masuk kekelas dengan kriteria yang telah ditentukan dan mulai wawancara dan observasi terhadap siswa/i dan melakukan pengukuran perkembangan anak dengan menggunakan kuesioner KPSP (kuesioner pra skrining perkembangan) sesuai usianya. Analisis yang digunakan univariat dengan menggunakan distribusi frekuensi dan bivariat dengan menggunakan uji chi square dengan $\alpha=(0,05)$.

\section{HASIL PENELITIAN}

\section{Analisis Univariat}

Gambaran Penggunaan Smartphone pada Anak Usia Pra Sekolah di TK AlMarhamah

Tabel. 1

Distribusi Frekuensi Penggunaan Smartphone pada Anak Usia Pra Sekolah

\begin{tabular}{ccc}
\hline Penggunaan Smartphone & F & $\%$ \\
\hline Sering & 24 & 72.7 \\
Jarang & 9 & 27.3 \\
\hline Jumlah & 33 & 100.0 \\
\hline
\end{tabular}


Berdasarkan tabel 1 dapat dilihat bahwa penggunaan smartphone anak usia pra sekolah di TK Al-Marhamah dengan anak sering menggunakan smartphone sangat medominasi yaitu sebanyak 24 anak $(72,7 \%)$ dan sisanya sebanyak 9 anak dinyatakan jarang $(27,3 \%)$. Sehingga lebih dari setengahnya anak usia pra sekolah di TK AlMarhamah Kabupaten Majalengka tahun 2017 adalah pengguna smartphone dengan frekuensi sering.

\section{Gambaran Perkembangan Personal Sosial Anak Usia Pra Sekolah di TK Al- Marhamah}

Tabel. 2

Distribusi Frekuensi Perkembangan Personal SosialAnak Usia Pra-Sekolah

\begin{tabular}{ccc}
\hline Perkembangan & F & $\%$ \\
Personal Sosial & 1 & 3.0 \\
Menyimpang & 15 & 45.5 \\
Meragukan & 17 & 51.5 \\
Sesuai & 33 & 100.0 \\
\hline Jumlah &
\end{tabular}

Berdasarkan tabel 2 dapat dilihat bahwa ada penyimpangan satu anak (3.0\%) dan meragukan sebanyak 15 anak (45.5\%) serta anak dengan perkembangan yang sesuai sebanyak 17 anak (51.5\%). Sehingga kurang dari setengahnya anak usia pra sekolah di TK Al-Marhamah Kabupaten Majalengka Tahun 2017 mengalami perkembangan yang meragukan.

\section{Analisis Bivariat}

Pengaruh Penggunaan Smartphone terhadap Perkembangan Personal Sosial Anak Usia Pra Sekolah di Tk Al-Marhamah

Tabel. 3

Pengaruh Penggunaan Smartphone terhadap Perkembangan Personal Sosial Anak Usia Pra-Sekolah

\begin{tabular}{|c|c|c|c|c|c|c|c|}
\hline \multirow{3}{*}{$\begin{array}{l}\text { Penggunaan } \\
\text { Smarphone }\end{array}$} & \multicolumn{6}{|c|}{$\begin{array}{c}\text { Perkembangan Personal Sosial } \\
\text { Anak Pra Sekolah }\end{array}$} & \multirow[t]{3}{*}{$p$ value } \\
\hline & \multicolumn{2}{|c|}{ Tidak Sesuai } & \multicolumn{2}{|c|}{ Sesuai } & \multicolumn{2}{|c|}{ Jumlah } & \\
\hline & $\mathrm{n}$ & $\%$ & $\mathrm{~N}$ & $\%$ & $\mathrm{n}$ & $\%$ & \\
\hline Sering & 15 & 62.5 & 9 & 37.5 & 24 & 100.0 & \\
\hline Jarang & 1 & 11.1 & 8 & 55.9 & 9 & 100.0 & 0.017 \\
\hline Total & 16 & 48.5 & 17 & 51.5 & 33 & 100.0 & \\
\hline
\end{tabular}

Hasil tabel 3 menunjukkan bahwa anak pra sekolah yang sering menggunakan smartphone dan dengan perkembangan tidak sesuai (62,5\%) lebih tinggi dibandingkan dengan anak yang jarang menggunakan smartphone dan dengan perkembangan tidak sesuai $(11,1 \%)$. Sehingga lebih dari setengahnya anak usia pra sekolah di TK AlMarhamah Kabupaten Majalengka Tahun 2017 adalah pengguna smartphone dengan frekuensi sering dan mendapatkan perkembangan yang tidak sesuai. 
Perbedaan proporsi ini bermakna secara statistic, dari hasil uji chi square pada taraf signifikasi 5\% $(\alpha=0.05)$ diperoleh nilai probabilitas p $0.017<0.05$, berarti hipotesis nol ditolak, sehingga dapat dinyatakan bahwa ada hubungan yang signifikan antara penggunaan smartphone dengan perkembangan personal sosial anak pra sekolah di Al-Marhamah Tahun 2017.

\section{PEMBAHASAN}

\section{Gambaran Penggunaan Smartphone pada Anak Usia Pra Sekolah}

Berdasarkan penelitian terhadap ibu atau orang tua murid menunjukan bahwa penggunaan smartphone pada anak usia pra sekolah di TK Al-Marhamah Kabupaten Majalengka tahun 2017 terbilang lebih dari setengah anak sering dalam menggunakan gadgetnya dengan jumlah sebanyak 24 anak (72.7\%) dari 33 sampel. Sementara sisanya sembilan anak dinyatakan jarang menggunakan smartphone (27.3\%).

Hal ini disebabkan pesatnya perkembangan teknologi sehingga anak tidak asing dengan dunia dagdet, ditambah dengan bermacam fitur didalamya sehingga ketertarikan anak semakin menjadi. Tentunya kejadian tersebut tidak lepas dari dampak yang timbul seperti anak lebih asik dengan dunianya sendiri (ketika anak bersama smartphone) yang seharusnya anak dengan usia pra sekolah adalah bermain dengan teman dan lingkungannya, tanpa pengawasan anak bisa terarahkan kepada konten-konten yang tidak semestinya seperti channel video, situs-situs terlarang, perkelahian atau pembuhuhan didalam game, ketergantungan teknologi dan lain sebagainya (Rahman, 2009).

Mendominasinya penggunaan smartphone pada anak merupakan kejadian yang mainstream untuk zaman sekarang, dilihat dari kemajuan dan perkembangan yang melesat begitu berpengaruh terhadap kehidupan masyarakat. Kementrian Komunikasi dan Informatika Republik Indonesia (2015) menjelaskan dalam situs resminya bahwa Indonesia adalah "raksasa teknologi digital Asia yang sedang tertidur". Jumlah penduduk Indonesia yang mencapai 250 juta jiwa adalah pasar yang besar. Pengguna smartphone Indonesia juga bertumbuh dengan pesat. Lembaga riset digital marketing Emarketer memperkirakan pada 2018 jumlah pengguna aktif smartphone di Indonesia lebih dari 100 juta orang. Dengan jumlah sebesar itu, Indonesia akan menjadi negara dengan pengguna aktif smartphone terbesar keempat di dunia setelah Cina, India, dan Amerika.

Bila dilihat dari Survei yang dilakukan oleh Kementerian Informasi dan UNICEF tahun 2014 yang mengelompokan komposisi usia, persentase pengguna gadget yang termasuk kategori usia anak-anak dan remaja di Indonesia cukup tinggi, yaitu 79,5 persen. Survei tersebut menggambarkan pula bahwa anak menggunakan gadget sebagian besar untuk mencari informasi, hiburan, serta menjalin relasi sosial. Adapun survei yang dilakukan oleh Indonesia Hottest Insight di tahun 2013 bahkan menunjukkan bahwa 40 persen anak di Indonesia sudah melek teknologi, atau disebut juga dengan active internet user.

Tentunya kehadiran teknologi canggih ini akan mempengaruhi perkembangan personal sosial anak. Karya ilmiah dari Tria Puspita Sari dan Amy Asma (2016). Mengemukakan bahwa gadget / smartphone memiliki dua dampak bagi personal sosial anak usia pra sekolah yaitu dampak positif dan dampak negatif. Anak pengguna gadget lebih senang memainkan gadgetnya daripada bermain dengan temannya, anak terkadang menirukan adegan kekerasan yang ada di game, anak bersikap acuh bila sudah di depan gadgetnya, dan lain-lain. 
Menurut Jovita Maria Ferliana (dalam Prianggoro, 2013) Psikolog dari RS Royal Taruma, dilihat dari tahapan perkembangan dan usia anak, pengenalan dan penggunaan gadget bisa dibagi ke beberapa tahap usia. Untuk anak usia di bawah 5 tahun jangan terlalu banyak memberikan kesempatan bermain gadget. Terlebih di usia ini, yang utama bukan gadget-nya, tapi fungsi orangtua. Pasalnya gadget hanya sebagai salah satu sarana untuk mengedukasi anak. Ia juga menjelaskan "Anak usia di bawah 5 tahun, boleh-boleh saja diberi gadget. Tapi harus diperhatikan durasi pemakaiannya".

Misalnya, boleh bermain tapi hanya setengah jam dan hanya pada saat senggang Menurut ahli psikolog anak Raviando dalam Kartika Setia (2016) mengemukakan "untuk anak usia di atas 6 tahun, penggunaan gadget hanya boleh 2 jam maksimal per hari. Sedangkan untuk anak 2-6 tahun, penggunaan smartphone hanya diperbolehkan maksimal 1 jam".

Penelitian diatas menunjukan bahwa frekuensi penggunaan smartphone pada saat ini sangat mendominasi, sesuai dengan karya ilmiah Novitasari dan Khotimah (2016) bahwa anak lebih sering menggunakan gadgetnya dengan data hasil observasinya bahwa dari 17 anak 14 diantaranya sering menggunakan smartphone. Begitupun menurut karya ilmiah Puspita Sari dan Mitsalia (2016) menyatakan dalam penelitiannya menunjukaan dengan angka paling tinggi yaitu kasus anak yang sering bermain smartphone dan dinyatakan bahwa dari 19 anak 18 diantaranya sering menggunakan.

Melihat begitu exisnya teknologi informasi ini dikalangan anak-anak dengan diikuti oleh pengaruhnya yang mampu menjadi bumerang bagi anak baik yang dapat menghasilkan positif atau negatif maka ada baiknya kita memperhatikan teori yang telah dikemukakan oleh tokoh sosiologi Travis Hirsch (dalam Nuredah, 2016) sebagai teori control social. Hirsch mengemukakan bahwa peran orang tua terhadap anak itu sangat penting diantaranya, attachment (kasih atau partisipasi), involvement (tanggung jawab), commitment (keterlibatan) dan belief (kepercayaan, kesetian, dan kepatuhan). Tentunya dalam pengawasan bermain smartphone, teori Hirsch ini sangat cocok dalam pengawasan lingkungan keluarga.

Upaya atau intervensi yang harus dilakukan bahwa penggunaan smartphone pada anak harus diperhatikan diantaranya adalah tidak terlalu banyak meberikan kesempatan anak untuk bermain dengan gadgetnya, karena secara ilmiah jika terlalu sering akan menimbulkan hal yang tidak baik terhadap perkembangan kedepanya, memang tidak salah jika anak dikenalkan terhadap gadget namun sebagai orang tua mau tidak mau sadar tidak sadar mereka dituntut menjadi smart parents yang harus cermat dalam memberikan sesuatu pada anak seperti smartphone sehingga dari teknologi tersebut orang tua mampu mengurangi pengaruh negatifnya dan mampu menambah wawasan serta kecerdasan pada anak atau menjadi alat memperdekat hubungan antara sang buah hati dan orang tua.

Selain itu perlu ada peraturan kedisiplinan dirumah yang diberitahukan pada anak dan orang tua murid bahwa pentinya memberikan durasi bermain smartphone sehingga seringnya anak dalam menggunakan dapat dikurangi, misalnya dalam seminggu hanya diperbolehkan dua kali menggunakan smartphone atau anak tidak diperbolehkan menggunakan dalam frekuensi tiap hari.

\section{Gambaran Perkembangan Personal Sosial Anak Usia Pra-Sekolah}

Berdasarkan penelitian menunjukan bahwa perkembangan anak usian pra sekolah di TK Al-Marhamah Kabupaten Majalengka tahun 2017 tercatat sebagian kecil anak mengalami penyimpangan $(3,0 \%)$, dan yang meragukan kurang dari setengah responden 
yaitu 15 anak (45,5\%), serta lebih dari setengan responden mengalami perkembangan yang sesuai sebanyak 17 anak (51,5\%). Anak dengan perkembangan yang tidak sesuai (menyimpang atau meragukan) merupakan anak dengan proses perkembangan yang tidak sesuai dengan pencapaian tugas-tugas sesuai umurnya, hal ini disebabkan berbagai faktor seperti proses biologis, pola asuh keluarga dan lingkungan. Masalah perkembangan personal sosial pada anak prasekolah diantaranya adalah anak tidak mempunyai kemampuan dalam bersosialisasi dan kemandirian mencapai angka 56,61\% pada anak usia prasekolah" (Galib Prasati Putri, 2013).

Perkembangan anak merupakan fase yang sangat penting untuk diperhatiakan karena pada masa kanak-kanak merupakan proses menuju kematangan. Penelitian diatas memperlihatkan bahwa perkembangan anak yang meragukan masih banyak walaupun lebih rendah dari perkembangan yang sesuai namun selisihnya hanya sedikit dan yang menyimpang hanya satu. Namun dari penelitian tersebut menunjukkan bahwa perkembangan sesuai dan yang tidak sesuai menunjukan selisih yang tidak terlalu besar. Seperti halnya karya ilmiah dari Trinika dkk (2015) ia menyatakan bahwa selisih perkembangan anak antar buruk dan baik hanya berbeda sedikit yaitu perkembangan baik $58,9 \%$ dan yang buruk $41,1 \%$.

Seorang ahli perkembangan anak John W. Santrock (2007) mengemukakan dalam bukunya, ada tiga kunci proses perkembangan yang sangat berhubungan erat diantara ketiganya yaitu proses biologis, kognitif, dan sosial-emosi. Mengutip argumentasi Widiastuti bahwa "Aspek perkembangan sosial dan emosional anak dapat dilihat dengan perkembangan personal sosial yang merupakan salah satu aspek yang dianggap paling penting untuk dikembangkan pada anak usia prasekolah sebagai dasar bagi perkembangan sosial selanjutnya. Masalah perkembangan personal sosial pada anak prasekolah diantaranya adalah anak tidak mempunyai kemampuan dalam bersosialisasi dan kemandirian mencapai angka 56,61 \% pada anak usia prasekolah" (Galib Prasati Putri, 2013).

Perkembangan personal sosial seorang anak tentunya disebabkan oleh beberapa faktor, secara umum Hurlock (2006) menjelaskan ada dua faktor yang disebutkan yaitu faktor keluarga dan faktor di luar keluarga. Sebuah gangguan terhadap personal sosial anak akan menyebabkan proses perkembangan terjadi gangguan dimana proses ini sangat berpengaruh untuk perkembangan selanjutnya.

Upaya atau intervensi menurut peneliti yang harus dilakukan terhadap perkembangan personal sosial anak usia pra sekolah diantaranya adalah memberikan informasi dan masukan kepada tenaga kesehatan atau keperawatan khususnya dalam keperawatan anak dan komunitas terhadap penerapan asuhan keperawatan anak serta dalam memberikan penyuluhan terhadap keluarga atau masyarakat umumnya tentangnya pemantauan proses perkembangan anak baik yang mampu menghambat atau mendukung perkembangan anak yang lebih matang. Perlu adanya kerja sama dalam pemantauan dan penyuluhan bersama pihak pemerintahan seperti dinas-dinas (Disdik dan Dinkes) terhadap anak usia pra sekolah tentang perkembangannya, karena tidak bisa dipungkiri bahwa anak merupakan generasi dimasa mendatang.

\section{Pengaruh Penggunaan Smartphone terhadap Perkembangan Personal Sosial Anak Usia Pra-Sekolah}

Hasil penelitian menunjukan data bahwa pengguna smartphone dengan frekuensi sering dan mendapatkan perkembangan yang tidak sesuai $(62,5 \%)$ lebih banyak daripada yang mendapatkan perkembangan sesuai (37,5\%), adapun dengan pengguna 
smartphone dengan frekuensi jarang dan mendapatkan perkembangan yang tidak sesuai $(11,1 \%)$ lebih rendah daripada yang mendapatkan perkembangan sesuai $(88,9 \%)$. Hasil menggunakan chi square pada penelitian adalah terdapat pengaruh antar penggunaan smartphone terhadap perkembangan personal sosial anak usia pra sekolah.

Sama halnya peneliti Novitasari dan Khotimah (2016) dalam karya ilmiahnya tentang dampak penggunaan gadget terhadap interaksi sosial anak usia 5-6 tahun menyatakan bahwa teknologi tersebut menimbulkan dampak terhadap inetraksi sosial. Penelitian tersebut selaras dengan penelitian yang dilakukan penulis, Novitasari meneliti dampak gadget lebih kearah negatif namun karya ilmiahnya tidak menjelaskan seberapa besar dampak tersebut.

Teori yang disampaikan oleh Iswidharmanjaya (2013) bahwa tidak selamanya gadget memiliki dampak negatif, gadget pun memiliki dampak positif apabila digunakan anak dengan lebih bijak yakni diantaranya merangsang untuk mengikuti perkembangan teknologi terbaru, meningkatkan kemampuan berbahasa, mengurangi tingkat stress, meningkatkan ketrampilan matematis, dan juga meningkatkan ketajaman penglihatan.

Berbeda dengan karya ilmiah Puspita Sari dan Mitsalia (2016) yang meneliti pengaruh penggunaan gadget terhadap personal sosial yang lebih pada pengaruh positifnya. Namun mereka juga menjelaskan bahwa teknologi tersebut banyak menimbulkan pengaruh negatif apabila tidak ada kontrol dari orang tua.

Melihat uraian diatas tentang permasalahan perkembangan sosial anak, sesuai dengan pendapat Erikson tentang perkembangan anak yang ditinjau dari aspek psikososial atau persenal sosial anak mengatakan bahwa anak dengan perkembangan selalu dipengaruhi oleh lingkungan sosial untuk mencapai kematangan kepribadian pada anak. Tugas perkembangan sosial dan pengaruh lingkunagan sosial yang berkaitan satu sama lain, tentunya kehadiran teknologi canggih akan mempengaruhi perkembangan personal sosial anak.

Menurut Badwilan (2004) ada beberapa pengaruh penggunaan smartphone diantaranya terhadap aspek psikologis, aspek sosial, aspek kesehatan dan aspek keuangan. Melihat dari aspek sosial yang dipengaruhi smartphone akan sangat berpengaruh terhadap permasalahan perkembangan personal sosial anak usia prasekolah dimana anak pada usia itu sering mengalami ledakan amarah, takut, iri hati ingin memiliki barang milik orang lain, adanya perasaan cemburu, umumnya anak terlihat agak malas dan pasif, jarang berpartisipasi secara aktif serta muncul perbedaan pemahaman antara kepercayaan dan keinginan seorang anak pada saat anak melakukan aktivitas bersama teman sebayanya (Rahman, 2009).

Menurut Muhammad Nazir dalam Wulandari (2015) seringnya menggunakan smartphone akan mengalami ketergantungan pada anak-anak membuat mereka menganggap bahwa smartphone itu segala-galanya bagi mereka. Mereka akan galau dan gelisah jika dipisahkan dengan gadget tersebut. Sebagian besar waktu mereka habis untuk bermain dengan teknologi tersebut. Akibatnya, kurangnya kedekatan dengan orang tua dan anak akan cenderung menjadi introvert.

Salah satu karya ilmiah oleh Novitasari, Khotimah (2016) menjelaskan bahwa kecenderungan penggunaan gadget termasuk smartphone secara berlebihan dan tidak tepat akan menjadikan seseorang bersikap tidak peduli pada lingkungannya baik dalam lingkungan keluarga maupun masyarakat. Selanjutnya ia mengatakan "ketidakpedulian seseorang akan keadaan disekitarnya dapat menjadikan seseorang dijauhi bahkan terasing dilingkungannya. 
Berdasarkan penelitian yang telah dilakukan memang dinyatakan bahwa smartphone memiliki pengaruh yang buruk terhadap perkembangan personal sosial anak usia pra sekolah di TK Al-Marhamah. Namun, sesuai yang penulis katakan bahwa pengaruh ini tidak bisa dilepaskan dari keterlibatan orang tua yang notabene yang bertanggung jawab terhadap keseharian anak. Peran orang tua sangat penting dalam perkembangan anak seperti yang dikemukakan oleh tokoh sosiologi Travis Hirsch dalam Nuredah (2016) tentang teori control sosialnya.

Upaya atau intervensi yang harus dilakukan bahwa pengaruh penggunaan smartphone terhadap perkembangan personal sosial pada anak usia pra sekolah harus diperhatikan diantaranya adalah kita perlu memilah bahwa kemajuan tenologi tersebut memiliki positif negatif yang perlu adanya filterisari. Tentunya perlu informasi dan pengawasan dari orang terdekat contohnya kakak, orang tua, atau guru disekolah agar anakpun belajar bijak dalam menggunakan.

Menurut penliti selain itu ada hal penting lainya yaitu memberikan informasi dan masukan kepada tenaga kesehatan atau perawat khususnya dalam keperawatan anak dan komunitas terhadap penerapan asuhan keperawatan anak serta dalam memberikan penyuluhan terhadap keluarga atau masyarakat umumnya tentang pengaruh pengguanaan smartphone terhadap perkembangan anak usia pra sekolah bahwa perlunya meminimalisir pengaruh negatif yang ditimbulkan teknologi tersebut terhadap perkembangan anak dengan lebih bijak dalam memberi dan mengawasi sang buah hati dalam bermain bersama smartphonenya sehingga kita dapat meningkatkan pengaruh positif terhadap perkembangan tersebut. 


\section{SIMPULAN}

Berdasarkan hasil penelitian pengaruh penggunaan smartphone terhadap perkembangan personal sosial anak usia pra sekolah di TK Al-Marhamah Kabupaten Majalengka Tahun 2017 dapat ditarik simpulan sebagai berikut :

Lebih dari setengahnya anak usia pra sekolah di TK Al-Marhamah Kabupaten Majalengka Tahun 2017 adalah pengguna smartphone dengan frekuensi sering dengan jumlah sebanyak 24 anak $(72,7 \%)$ dari 33 sampel.

Kurang dari setengahnya anak usia pra sekolah di TK Al-Marhamah Kabupaten Majalengka Tahun 2017 mengalami perkembangan yang meragukan dengan jumlah sebanyak 15 anak (45,5\%).

Ada hubungan yang signifikan antara penggunaan smartphone dengan perkembangan personal sosial anak pra sekolah di Al-Marhamah Kabupaten Majalengka Tahun 2017 karena diperoleh nilai probabilitas p $0.017<0.05$ (Ho ditolak karena $\mathrm{p}$ value $<\alpha)$.

\section{SARAN}

Sehubungan dengan penelitian diatas, maka dapat dikemukakan sebagai berikut:

1. Bagi TK

Hasil penelitian ini diharapkan menambah informasi tentang pengaruh penggunaan smartphone terhadap perkembangan personal sosial anak usia prsekolah dan sebagai gerakan pembaharuan agar setiap guru dapat mengingatkan kepada muridnya bahwa perlunya ada batasan waktu dalam menggunakan smartphone serta memberikan penegasan kepada orang tua murid untuk menjadi smart parent khususnya dalam pengawasan anak menggunakan gadgetnya di rumah.

\section{Bagi Orang Tua}

Diharapkan penelitian ini bisa menjadi informasi tentang pengaruh penggunaan smartphone terhadap perkembangan personal sosial anak usia pra sekolah kepada orang tua bahwa orang tua sangat berperan penting terhadap baik buruknya pengaruh teknologi terhadap sang buah hati, oleh karena itu kebijakan dalam mengawasi anak sangat ditekankan terutama dalam bemain dan berinteraksi.

\section{Bagi Peneliti Lain}

Perlu diketahui bahwa pengaruh penggunaan smartphone terhadap perkembangan personal sosial anak itu sangat penting untuk diteliti, mengingat kemajuan teknologi dari tahun ke tahun sangat pesat oleh karenanya diharapkan penelitian ini bisa menambah informasi dan referensi sebagai rujukan sumber data serta mampu menjadi acuan untuk penilitian selanjutnya agar lebih dikembangkan dengan variabel perkembangan anak yang berbeda seperti perkembangan fisik, perkembangan kognitif, perkembangan bahasa dan perkembangan emosional anak. 


\section{DAFTAR PUSTAKA}

Efendi, F. (2013). Pengarug Gadget terhadap Perkembangan Anak Usia Dini.skripsi, Teknik Informatika Universitas Brawijaya

Elcom. (2011). Google Android. Jakarta: Andi Publiser

Goleman, D. (2016). Social Intelligence. Jakarta: PT. Gramedia Pustaka Utama Hurlock, E. B. (2006). Perkembangan Anak Jilid 1. Jakarta: Penerbit Erlangga Iswidharmanjaya. (2013). Bila Si Kecil Bermain Gadget. Surabaya Beranda Agency

Kementrian Komunikasi dan Informatika RI. (2015). Indonesia Raksasa Teknologi Digital Asia. Dalam www.kominfo.go.id Diakses 02 Oktober 2015

Novitasari, W \& Khotimah, N. (2016). Dampak Penggunaan Gadget terhadap Interaksi Sosial Anak Usia 5-6 Tahun. Journal PAUD Teratai, 5(3), 2016

Nugraha, A. \& Rachmawati, Y. (2008). Metode Pengembangan Sosial Emosional. Jakarta: Penerbit Universitas Terbuka

Nuredah. (2016). Peran Orangtua dalam Penanggulangan Dampak Negatif Handphone Pada Anak. Fakultas Ilmu Sosial dan Humaniora Universitas Islam Negeri Sunan KalijagaYogyakarta

Nuzlia, Firly laily. (2015). Hubungan Intensitas Penggunaan Smartphone oleh ibu terhadap Hasil Deteksi Dini Perkembangan Sosial-Emosional Anak Prasekolah. (Program Studi Ilmu Keperawatan Fakultas Kedokteran Universitas Gadjah Mada Yogyakarta)

Prianggoro, H. (2013). Anak dan Gadget: yang Penting Aturan Main. http://nakita.id/Balita/Anak-Dan-Gadget-Yang-Penting-Aturan-Main. Diakses 13 Oktober 2013

Putri, G. P. (2013). Perbedaan Perkembangan Personal Sosial Anak Usia Pra Sekolah dengan Pola Asuh Demokratis dan Otoriter. S1 Keperawatan Universitas Jember

Rahman. (2009). Karakteristik Perkembangan Anak Usia Dini. Jurnal Kesehatan

Santrock, J. W. (2007). Perkembangan Anak, (terjemahan). Jakarta: Penerbit Erlangga

Sari, T. P \& Mitsalia, A. A. (2016). Pengaruh Penggunaan Gadget terhadap Personal Sosial Anak. Journal Profesi, 13(2), Maret 2016

Setia, U. K. (2016). Ikuti Batasan Waktu Main Gadget Sesuai Usia. Dalamwww.liputan6.com. Diakses Jakarta, 24 Februari 2016 pukul 17.00 WIB

Tondok, Marselius Sampe. (2013). Penggunaan Smartphone pada Anak: Be Smart Parent. Dalam Harian Surabaya Post, 24 Maret 2013

Trianto.(2010). Mengembangkan Model Pembelajaran Tematik. Penerbit: PT. Prestasi Pustakaraya - Jakarta

Trinika, Y. (2015). Pengaruh Penggunaan Gadget terhadap Perkembangan Psikososial Anak Usia Pra Sekolah (3 - 6 Tahun) di TK Kristen Immanue. (Program Studi Keperawatan Universitas Tanjungpura)

Williams, B. K. \& Sawyer, S. C. (2007). Using Information Technologi : Pengenalan Praktis Dunia Komputer \& Komunikasi Edisi 7. (Penerjemah : Nur Wijayaning Rahayu \& Th. Arie Prabawali) Yogyakarta: Andi

Wong, D. (2009). Buku Ajar Keperawatan untuk Pediatrik. Jakarta: EGC

Wulandari, A. (2015). Pengaruh Gadget terhadap Perkembangan Anak. (Fakultas Sains dan Matematika Universitas Diponegoro)

Wulandari, Primati, Y. (2016). Anak Asuhan Gadget. Dalam www.liputan6.com. Diakses Jakarta, 17 Maret 2016 pukul 11.00 WIB 
Wulandari, R. (2015). Komunikasi Antar Pribadi Orangtua dan Anak dalam Penggunaan Gadget. Bandung: Universitas Islam Bandung, Fakultasi Ilmu Komunikasi 